\title{
Standard Implementation of Teaching Factory 6 Step Model (TF-6M) Learning
}

\author{
D. Hidayat, A.Suherman, Sudjani, \\ Faculty of Technology and Vocational Education \\ Universitas Pendidikan Indonesia \\ J1. Dr. Setiabudhi No. 229 Bandung 40154 \\ e-mail: dadongupi@yahoo.co.id
}

\begin{abstract}
Learning Teaching Factory 6 Steps Model (TF6M Model) is a learning model that can create industrial climate at schools, can improve students' competencies and can produce vocational students with entrepreneur spirit. TF-6M Model as a concept had been refined through researches that strengthened the concept, resulting in formulation of the operational implementation of the model. The formulation consists of the implementation of TF-6M Model at skill competency, which integrates a particular productive subject or several productive subjects combined with entrepreneur subjects and is held in time block coupled with Industrial Working Practices (Praktek Kerja Lapangan (Prakerin)) followed by a competency test and ended with a development of Map/Web Rehearsal-based entrepreneur craft. TF-6M Model was implemented in class XI on Culinary skill competency at SMK 3 Garut and Refrigeration and Air Control skill competency at SMK TI Cimahi. In the implementation of TF-6M Model in both skill competencies, the indicators of students' soft skill and hard skill competencies can be achieved perfectly, including the entrepreneurship competency. Implementation Standards of TF-6M Model, which can be used as a common reference in implementing TF-6M Model, were also produced. Implementations Standards of TF6M Model consists of: 1 . Preparation of implementation, which includes: - changing the management/school climate into industrial climate; - Practicing communication; and - exercising order analysis. 2. Implementation, which includes: - preliminary stage; - core stage; and concluding/evaluation stage. The strategies, approaches and learning methods in standard implementation of TF-6M Model consist of: problem solving; scientific approach; inquiry discovery; question and answer method; discussions; role play; Contextual Teaching Learning (CTL); social consensus; reel job; reel teaching; authentic learning and authentic evaluation, problem-based learning; production-based learning. Implementation of TF-6M Model requires dedication because the obstacles and challenges during early stages need to be overcome. These obstacles and challenges consist of: 1. the ability to convince the principals to implement TF-6M Model since the implementation requires principals' policies; 2 . the resistances from teachers because they dislike/feel disturbed by changes; - overestimate/underestimate TF-6M Model; - show unprofessional attitude. Teachers who are expected and required to run this model are productive teachers who love vocational competencies and teaching profession.
\end{abstract}

Keywords-TF-6M Model; productive and entrepreneurship subjects; soft skills and hard skills competency; standard implementation; strategies, approaches and methods of learning, professional.

\section{INTRODUCTION}

The number of Vocational Schools (Sekolah Menengah Kejuruan (SMK)) increases significantly because of the policy of Renstra Depdiknas 2005, which set the proportion of SMK:SMA students in 2015 to be 70:30 [1]. Currently, the number of vocational schools in Indonesia is 12.812 [2], which is a fantastic increase compared to 6000 schools in 2008. This number looks delightful although its quality should be examined closely.

Vocational school as a sub-system of national education system continues to improve and increase both in quantity and quality of its education results. Vocational schools should prepare their graduates to be capable to work as tradesmen or experts with the knowledge, skills, and working attitudes in accordance with the needs and demands of Business World and Industrial World (Dunia Usaha dan Dunia Industri ((DuDi)) or for entrepreneurship.

General and specific purposes of vocational schools are: "... (f) to prepare the students to be able to work, either working independently or filling vacancies available in the business world and industrial world as middle-level labors, based on their field and skill program of interest; ( $g$ ) to equip the students to be able to choose careers, to be tenacious and persistent in the competition, and to be able to develop professional attitude in their expertise field of interest. " [1].

While UNESCO [3] emphasized that the implementation of technology and vocational education is as follows;

"Technical and vocational education as preparation for an occupational field should provide the foundation for productive and satisfying careers and should ... lead to the acquisition of broad knowledge and generic skills applicable to a number of occupations within a given field so that the individual is not limited in his/her choice of occupation and is able to transfer from one field to another during his/her working life..."

The purposes of vocational schools as stated in UU No 20/2003 Article 18 and the elucidation of Article 15 should be the main reference for vocational schools and should be reflected in the Vision, Missions and working programs. This is important because vocational school as sub-system of national education is truly expected by the nation. Current population of Indonesia, which is already over 250 million, will become a disaster when the youth manpower is not productive or, in other words, is incapable of working. Real 
competition with the passing of MEA era is the real challenge and it begins to be strongly felt, therefore, the government should be serious in developing vocational school curriculum, facilitating and running it in accordance with PP 19/2005 about Education Standards. Vocational schools can be expected to contribute greatly in improving the quality of Indonesian human resources, in order to increase national income and productivity in anticipating the impact of global changes.

Directorate of Development of Vocational Schools (Direktorat Pembinaan SMK) has taken strategic steps of Programs and Policies of 2016 with Strategies of Development of Vocational School Qualities, these are:

"Procurement of Infrastructure at vocational schools; Clustering the vocational schools with the Development of Reference vocational schools; Harmonization of Vocational Competency with Industrial Requirements and Vocational Package Review; Provision of Productive Teachers; Improvement of Learning Quality; Standardization, Certification and Assurance of the Quality of Vocational Graduates" with one of its main performances supports the achievement of the Development of Teaching Factory and Techno park at vocational schools in accordance with the 6th NAWACITA [4], which projected vocational graduates as follows: $20 \%$ becoming entrepreneurs, $50 \%$ working domestically, $10 \%$ working abroad and $10 \%$ continuing to Colleges [4]

Educational innovations lead to the development of life skills, with an integrated learning and contextual teaching and learning model, which is a learning model that leads to the development of life skills [3]. Government launched the "Vocational School-Based Industrial Program" in order to boost regional economic growth with the approach of Manufacturing Industry Teaching Model, which aims: 1) to support regional economic growth; 2) to expand the labor market; 3) to produce inexpensive goods of domestic production; 4) to increase rupiah turnover domestically (Multiplier Effect); 5) to improve the quality of national human resources; 6) to increase the resilience of the Indonesian economy.

Research results showed: "the students who undertook internship at schools possess much better competencies than the students who undertook internship in the industry, and can develop when working both in domestic companies or overseas companies" [5] This means that, if schools conduct industrial process through teaching factory at schools properly and position the students like they work in the industry, the students, in addition to taking productive subjects, will also gain industrial experience such as industrial working practices with undoubted industrial abilities.

Policies which have been launched must be conducted consistently. The massive grow of vocational schools requires serious measures in order not to be a boomerang for Indonesian vocational education. Another data showed that the number of unemployed vocational graduates hold the highest record of $12.5 \%$ of 7.56 million people [6]. The Minister of Manpower further stated that unemployed vocational graduates exist because: "Perhaps the competencies have not been mixed with the industry or his/her (vocational graduates) abilities do not fit."

Meanwhile nowadays there is a huger number of unemployed people as a result of layoffs by various companies, in August 2015 this number reached 7.56 million people. (320 thousand people suffered layoff in 2014) [6]. A comment regarding this matter came from Alexander Kevin J @ detiklovers-indo 07-11-2015 00:23:51. He put forward his suggestions: ....... "Don't be desperate. Find capital and funding for UKM, open your own business. Take risks. Don't just rely on finding employment, but create your own employment. "

In an effort to achieve the purposes of vocational schools in accordance with the regulations, in school level, Industrial Working Practice (Praktek Kerja Industri (Prakerin)) has been developed and formulated by PSMK by the Directorate PSMK, which stated that:

"Prakerin is a pattern of the implementation of education and training which is managed jointly by vocational schools and Industry/Profession Association as institutional partners, starting from planning, implementation, evaluation and certification, which constitute an integral program using various alternative implementation, such as day release, block release etc. .[3]"

However, the practice is not always smooth, various conditions give effects, for example school infrastructure, industrial partners, educators and even principals as policy makers who are very varied.

Concerning the implementation of Prakerin, Martawijaya DH in his book Model Pembelajaran Teaching M Factory 6 Steps (TF-6M) suggested that there are four approaches in implementing prakerin, namely:

"...... It can be concluded that industrial working practice (Prakerin) in vocational schools can be done with 4 (four) patterns, namely: 1. Implementation of Prakerin in learning using dual system approach; 2. Implementation of Prakerin in learning using teaching factory approach, 3. Implementation of Prakerin in learning using teaching industry approach, 4. Implementation of Prakerin for schools that cannot meet the three learning model approaches above. [3].

\section{METHODS}

Subjects whose learning process used TF-6M Model, Time and Place and Research Methods.

\section{A. Subject:}

- Pasiteri skill competency: Indonesian Regional Foods; Continental food; Serving Manner and Food Manner; Digital Simulation.

- Refrigeration and Air Management skill competency: Refrigeration System and Installation; Air Management System and Installation; Refrigeration and Air Management Control; each skill competency is combined with entrepreneurship subjects. 


\section{B. Time and Place}

The second year the study began with dissemination into a number of vocational schools and continued with permanent implementation of TF-6M model at two vocational schools in two skill competencies: patiseri (culinary) at SMK 3 Garut, and refrigeration \& air management at SMK IT Cimahi. The permanent implementation of TF-6M model and time block is done during semester V in class XII.

Research Method: Descriptive research used evaluation approach, both in dissemination and implementation. Evaluation research used is emphasized more on formative evaluation instead of evaluative one.

\section{RESULTS AND DISCUSSION}

An example of Teaching Factory learning model is Teaching Factory 6 Steps (TF-6M) Model, which is a teaching factory learning model that can produce vocational graduates who are able to fill job vacancies in business world and industrial world as middle-level workers as well as able to work independently, because TF-6M can help the students to achieve academic, social and vocational competencies as well as gain entrepreneur soul.

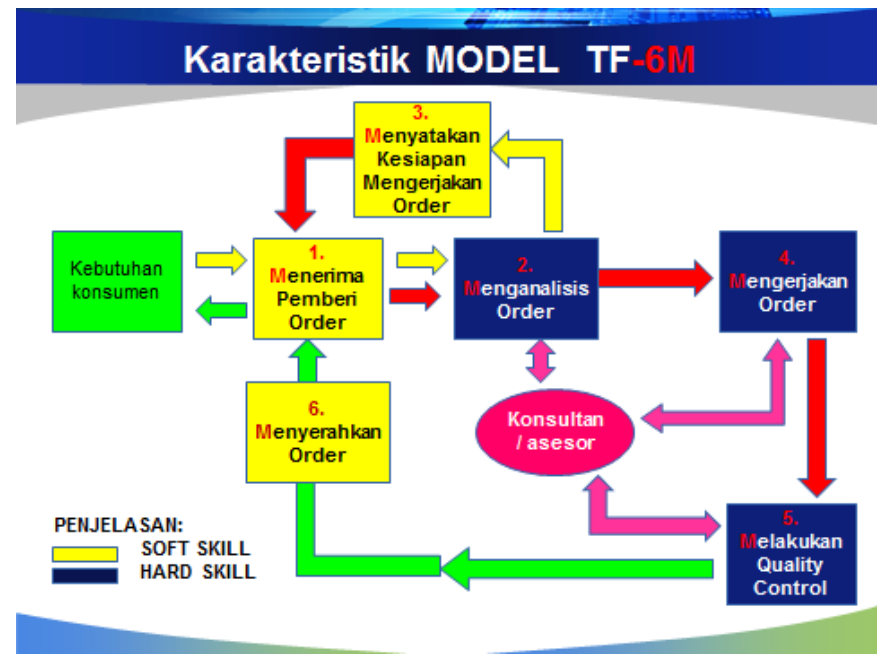

Fig. 1. Scheme of TF-6M Model [5]

\section{A. Preparation of the Implementation of TF-6M}

Preparation for the implementation of TF-6M Model began with determining which productive subjects will be implemented using TF-6M Model, in addition to Entrepreneurship subject. Further preparation includes the preparation of administration, learning/training materials, materials, machinery and tools, Learning Plan (Rencana pelaksanaan Pembelajaran (RPP)). *) This is followed by three main activity stages: preliminary stage, core stage and evaluation stage, as follows:

\section{B. Preliminary Stage}

Encouraging students to change management (climate) of schools into management (climate) of industry rationally, with teachers and students discussing various arguments and agreeing on an alternative model (TF-6M Model). In the implementation, the strategies, approaches and learning methods used consist of: problem solving; inquiry discovery; Cara Belajar Siswa Aktif (CBSA); scientific approach; social consensus; and role play.

Communication exercise is a teaching material that is an asset for entrepreneurs. This material explains communication, gives examples of cases and gives examples of good communication. In this step, students practice communication in receiving the order, expressing willingness to work on the order and submitting the working result to customer. The strategies, approaches and learning methods used in communication exercise consist of: Cara Belajar Siswa Aktif (CBSA); 4-steps method; role play; Contextual Teaching Learning (CTL); and social agreement;;

Order analysis exercise: The learning process of productive subjects whose theories and concepts chosen using TF-6M Model with CTL approach. For example, on machinery skill competency, this exercise guides the students to read pictures and to determine the materials, machines, cutting tools, engine speed, counting time, price, and working safety. The strategies, approaches and learning methods used in the implementation of the order analysis exercise *) consist of: problem solving; Cara Belajar Siswa Aktif (CBSA); inquiry discovery; problembased learning; production-based learning; discussion; Contextual Teaching Learning (CTL); reel job; reel teaching; authentic learning and authentic evaluation.

\section{C. $\quad$ Core Stage}

- RECEIVING ORDER: Soft skills: Communicating using competencies: personal, social, academic and vocational; strategies, approaches and learning methods: drill (exercise with reel job); role play; Contextual Teaching Learning (CTL); social consensus; reel job; authentic learning and authentic evaluation.

- ANALYZING ORDER: Hard skills: Analyzing Order: academic and vocational competence: reading pictures and determining materials, machines, cutting tools, engine speed, counting time, price, and working safety. *) (with consultation with consultants). Strategies, approaches and learning methods: drill (exercise with reel job); role play; Contextual Teaching Learning (CTL); reel job; authentic learning and authentic evaluation; reel teaching; problem-based learning; production-based learning.

- EXPRESSING THE READINESS TO WORK ON THE ORDER: Soft skills: Communicating with competencies: personal, social, academic and vocational; Using the results of the analysis of the order, with full confidence the worker expressed the readiness to work on the order based in the technical requirements, with polite speech; strategies, approaches and learning methods: drill (exercise with reel job); role play; social consensus; Contextual Teaching Learning (CTL); reel job; authentic learning and authentic evaluation. 
- WORKING ON THE ORDER: Hard skills: Working on the order using academic and vocational competencies; by applying the working safety, conducting working preparation and working steps based on SOP, assessing the working results and calculating working time adjusted with working standards; (with consultation with consultants). *); strategies, approaches and learning methods: drill (exercise with reel job); role play; reel job; authentic learning and authentic evaluation; production-based learning; reel teaching;

- QUALITY CONTROL: Hard skills: Performing quality control using academic and vocational competencies; Performing quality control, matching the size, level of precision and function of the work pieces, in accordance with the working drawings; (with consultation with consultant) *); strategies, approaches and learning methods: drill (exercise with reel job); role play; reel job; authentic learning and authentic evaluation; reel teaching; problem-based learning; production-based learning.

- SUMBITTING THE ORDER TO THE CUSTOMER: Soft skills: Communicating using competencies: personal, social, academic and vocational; Speaking politely when submitting the work, requesting feedback from the customer about the work, trying to establish good communication with the customer. *) Strategies, approaches and learning methods used: drill (exercise with reel job); role play; reel job; authentic learning and authentic evaluation; reel teaching; problem-based learning; production-based learning.

\section{Evaluation Stage}

From the implementation of TF-6M Model on those two skill competencies: Preparation and implementation of TF-6M Model, even though it required a relatively hard effort, can eventually be conducted properly in accordance with the characteristic provisions of TF-6M Model. The indicators of subject competencies whose implementation used TF-6M Model were achieved properly.

\section{E. Research Findings}

Permanent Implementation of TF-6M Model in those two skill competencies produced:

- Indicators of students' soft skill and hard skill competencies can be achieved perfectly, added with the development entrepreneurship competency;

- Implementation Standards of TF-6M Model were generated as Procedure Operating Standards in implementing TF-6M Model.

- Obstacles and Challenges: 1. the ability to convince the principals to implement TF-6M Model since it requires principal's policy; 2. Possible resistances from the teachers, which include: disliking/feeling disturbed by changes; overestimating/underestimating TF-6M
Model; not mastering vocational competency capabilities; or showing unprofessional attitude.

- Teachers who are expected/required to perform TF-6M Model are: - productive teachers who master vocational competency capabilities; - teachers who love vocational competency and possess entrepreneurship spirit; - and professional teachers who loves their profession.

\section{CONCLUSIONS}

Implementation formulation of TF-6M that was produced is as follows: The implementation of TF-6M Model combined one or several Productive Subjects with Entrepreneurship Subject and was held in time Block of one semester, added with the implementation of Prakerin, followed by Competency Test and ended with Map/Web Rehearsal-based Entrepreneur Craft Development.

The development of entrepreneur craft began when the students were given problem-solving when designing visits to industry in order to change the school climate into industrial climate. While visiting the industry, they became aware of the reality about business world/industrial world that is interesting and challenging. They were interested to explore those skill competencies, so they became excited to practice because they wanted to master vocational competencies, hard skills and soft skills, they realized the desires by designing a form of business that will be run using Map/Web Rehearsal approach. Therefore the practice of entrepreneurship subjects will be in accordance with students' skill competencies.

Based on the results of dissemination and implementation of TF-6M Model that had been conducted, field data related to policy makers by the School Principals was obtained, in which the author found a number of doubting principal; some wanted to but were not brave enough to make policies; some want to and were brave enough to make policies but did not own the required infrastructure; few showed interest in TF-6M Model and made policies. Based on this fact in the effort to disseminate TF-6M Model to produce standardized vocational graduates, the policy from higher institution, that is, the Directorate of Development of Vocational Schools, is still required.

\section{References}

[1] Martawijaya, D.H (2014). Model Pembelajaran Teaching Factory 6 Langkah (Model TF-6M).Edisi 2 Bandung. Diterbitkan Terbatas

[2] Dapodikmen,16 Nov.2015. Kementrian Pendidikan dan Kebudayaan. Jakarta.

[3] Martawijaya, D. H. (2010). Keberhasilan Uji Kompetensi Siswa Dilihat Dari Pelaksanaan Praktek Kerja Industri (Prakerin). Laporan Penelitian LPPM Universitas Pendidikan Indonesia, Bandung

[4] ------.-Pengembangan SMK Tahun 2015-2019\&Quick-Wins Direktorat Pembinaan SMK

[5] Martawijaya (2010). Pengembangan Model Pembelajaran Teaching Factory 6 Langkah (Model TF-6M) Untuk Meningkatkan Kompetensi Siswa Dalam Mata Pelajaran Produktif Sekolah Menengah Kejuruan (Studi Peningkatan Kompetensi Siswa dalam Mata Pelajaran Produktif Kompetensi Keahlian Teknik Pemesinan SMK Negeri 6 Bandung). Disertasi Program Studi Pengembangan Kurikulum SPs Universitas Pendidikan Indonesia 2010.

[6] Detikcom.2015/11/06 17:46:01 Angling AdhityaPurbaya-detikNews. 